\title{
SUBSITUSI DEDAK PADI DENGAN POD KAKAO YANG DIFERMENTASI DENGAN Aspergillus niger TERHADAP PERFORMANS BROILER UMUR 6 MINGGU
}

\author{
(Substitute Rice Bran with Fermented Pod Cocoa by Aspergillus niger \\ On Broiler Performance Age 6 Weeks)
}

\author{
Eljune R.P Habeahan ${ }^{1}$, Armyn Hakim Daulay ${ }^{2}$ dan Zulfikar Siregar² \\ 1. Mahasiswa Program Studi Peternakan-Fakultas Pertanian \\ 2. Staf Pengajar Program Studi Peternakan-Fakultas Pertanian
}

\begin{abstract}
The need for increasing animal protein consumption causes the number of rations consumption increased too. While the availability of feed ingredients such as rice bran increases, the required feed ingredient that can replace rice bran. This research aimed to determine the effect of substitution of pod cocoa husk fermented with Aspergillus niger to ration consumption, body weight gain and feed conversion ratio (FCR) of Broiler. The design that used in this study was completely randomized design with 6 treatments and 4 replications. Each replication consists of 5 tails Day Old Chick (DOC). The Treatments consists of RO (Commercial Feed), R1 (the use of rice bran $12 \%$ and without fermented pod cacao), $R 2$ (the use of rice bran $9 \%$ and fermented pod cacao $3 \%$ ), $R 3$ (the use of rice bran $6 \%$ and fermented pod cacao 6\%), R4 (the use of rice bran 3\% and fermented pod cacao $9 \%$ ), $R 5$ (the use of rice bran $0 \%$ and fermented pod cacao 12\%). The research results showed the average ration consumption ( $g$ / head / week) 94.21; 94.40; 95.87; 93.21 and 377.69. Mean weight gain ( $\mathrm{g} / \mathrm{head} /$ week) 44.89; 44.84; 45.76; 46.32 and 181.80. Average conversion ratio $2.13 ; 2.12 ; 2.11 ; 2.03$ and 8.39. The results showed that the substitution of rice bran with fruit fermented cocoa pods in the ration was not significantly different $(P>0.05)$ on ration consumption, but significantly different $(P>0.05)$ on body weight gain and the conversion ratio of broiler chickens. The conclusion of this research that substitution of rice bran with pod cocoa still be used up to $6 \%$ on broiler rations age 6 week (42 day).
\end{abstract}

Keywords: Substitution, rice bran, cocoa pods, fermented, Aspergillus niger, broiler.

\begin{abstract}
ABSTRAK
Kebutuhan protein hewani yang semakin meningkat mengakibatkan jumlah konsumsi ransum semakin meningkat juga. Sementara ketersediaan bahan pakan seperti dedak padi semakin meningkat, maka dibutuhkan bahan pakan yang dapat menggantikan dedak padi. Penelitian ini bertujuan untuk mengetahui pengaruh subsitusi dedak dengan pod kakao yang difermentasi Aspergillus niger terhadap konsumsi ransum, pertambahan bobot badan dan konversi ransum Broiler. Rancangan yang digunakan dalam penelitian ini adalah Rancangan Acak Lengkap (RAL) dengan 6 perlakuan dan 4 ulangan. Setiap ulangan terdiri dari 5 ekor Day Old Chick (DOC). Perlakuan terdiri dari $\mathrm{R}_{0}$ (Pakan Komersial), $\mathrm{R}_{1}$ (penggunaan dedak padi $12 \%$ dan tanpa kulit buah kakao fermentasi) , $\mathrm{R}_{2}$ (penggunaan dedak padi 9\% dan kulit buah kakao fermentasi 3\%), $\mathrm{R}_{3}$ (penggunaan dedak padi 6\% dan kulit buah kakao fermentasi 6\%), $\mathrm{R}_{4}$ (penggunaan dedak padi 3\% tanpa kulit buah kakao fermentasi 9\%), $\mathrm{R}_{5}$ (penggunaan dedak padi $0 \%$ dan kulit buah kakao fermentasi 12\%). Hasil penelitian menunjukan rataan konsumsi ransum (gram/ekor/minggu) 96,08; 94,93; 94,66; 94,24, 94,00 dan 92,64. Rataan pertambahan bobot badan (gram/ekor/minngu) 54,99; 45,63; 45,47; 45,13, 41,41 dan 40,06. Rataan konversi ransum 1,75; 2,08; 2,08; 2,09, 2,27 dan 2,32. Hasil penelitian menunjukan bahwa subtitusi dedak dengan pod kakao fermentasi dalam ransum tidak berbeda nyata $(\mathrm{P}>0.05)$ terhadap konsumsi ransum, namun berbeda nyata $(\mathrm{P}>0.05)$ terhadap pertambahan bobot badan dan konversi ransum ayam broiler. Kesimpulan dari penelitian ini adalah subsitusi dedak padi dengan pod kakao masih bisa digunakan sampai $6 \%$ pada ransum ayam broiler umur 6 minggu (42) hari.
\end{abstract}

Kata kunci : Subsitusi dedak, pod kakao, fermentasi, Aspergillus niger, broiler. 


\section{PENDAHULUAN}

Kebutuhan protein hewani terus meningkat seiring dengan pertambahan penduduk dan meningkatnya kesadaran masyarakat akan pentingnya zat gizi. Usaha ternak unggas merupakan salah satu upaya memenuhi kebutuhan protein hewani,diantaranya adalah ayam broiler. Ayam broiler memiliki potensi yang sangat besar untuk di kembangkan karena laju pertumbuhan bobot badannya yang jauh lebih cepat dibandingkan dengan unggas lain.

Masalah yang umum dihadapi oleh peternak akibat adanya penambahan populasi ternak, yaitu terbatasnya pakan. Pakan merupakan hal vital yang harus dicukupi kebutuhannya bagi ternak, sehingga ternak dapat berproduksi dengan baik dan maksimal. Ternak harus mendapatkan asupan pakan yang seimbang baik dari segi kualitas maupun segi kuantitas. Namun bahan baku yang umum digunakan sebagai bahan ransum kini mengalami peningkatan harga, dedak padi contohnya, kebutuhan yang terus meningkat menyebabkan harganya juga ikut mengalami kenaikan. Memperhatikan nilai ekonomi dedak padi, perlu dilakukan inovasi untuk mencari pengganti dedak padi dengan bahan baku pakan yang baru. Sebagai bahan pengganti dedak, bahan tersebut harus memiliki nilai nutrisi yang sama dengan dedak. Bahan tersebut harus memenuhi kriteria sebagai bahan pakan, jumlahnya dan ketersediaannya harus terjamin sepanjang tahun, tidak membahayakan bagi ternak, bukan merupakan komoditas yang bersaing dengan manusia, serta syarat-syarat lain sebagai bahan pakan (anggorodi, 1995).

Sebagian besar masyarakat kita yang berprofesi sebagai petani, menghasilkan banyak limbah pertanian dan perkebunan yang dapat dimanfaatkan sebagai pakan ternak diantaranya adalah pod kakao. Kulit kakao dapat diberikan pada ternak dalam bentuk segar maupun diolah dahulu menjadi tepung sebagai bahan pakan. Pod kakao dapat dimanfaatkan sebagai pakan ayam broiler untuk mensubtitusi dedak padi.

Sumatera utara merupakan sentra perkebunan,termasuk perkebunan kakao yang sangat luas,sampai tahun 2005 menurut Siregar (2005) luasan lahan perkebunan kakao adalah 57.903,82 Ha,diikuti hasil samping berupa kulit buah kakao yang melimpah.

Proses pengolahan pod kakao ada dua cara yaitu dengan fermentasi dan tanpa fermentasi. limbah pod kakao dapat difermentasi terlebih dahulu dengan tujuan menurunkan kadar lignin yang sulit dicerna oleh hewan dan untuk meningkatkan kadar protein. Dengan adanya fermentasi 
maka kualitas dan nilai gizi ransum akan meningkat ( Amirroenas ,1990). Hasil analisi kandungan nutrisi pod kakao fermentasi dengan Aspergillus niger adalah protein kasar $(12,89)$,energi metabolisme ( 1767,8642), lemak kasar (2,961), serat kasar (21,031), ( Laboratorium Nurtisi dan Bahan Pakan Ternak, Program Studi Peternakan,Fakultas Pertanian, Universitas Sumatera Utara,2012 )

Berdasarkan uraian tersebut, penulis tertarik untuk melakukan penelitian yang berjudul "Subtitusi dedak padi dengan pod kakao yang difermentasi dengan Aspergillus niger terhadap performans ayam broiler umur 6 minggu".

\section{BAHAN DAN METODE PENELITIAN}

\section{Tempat dan Waktu Penelitian}

Penelitian dilaksanakan di Laboratorium Biologi Ternak Jln. Prof. Dr. A Sofyan No.3 Program Studi Peternakan Fakultas Pertanian Universitas Sumatera Utara. Penelitian ini berlangsung selama 6 minggu dimulai dari Bulan Juli sampai dengan Agustus 2012.

\section{Bahan dan Alat}

\section{Bahan}

Day old chick (DOC) yang digunakan sebagai objek penelitian sebanyak 120 ekor strain Cobb - LH 500 BB 43.79167 2.56662.Bahan penyusun ransum terdiri atas tepung jagung, dedak padi, bungkil kedelai, tepung ikan, minyak nabati, tepung pod kakao fermentasi, kapur dan top mix. Air minum untuk memenuhi kebutuhan air dalam tubuh diberikan secara ad libitum. Air gula untuk mengurangi stress dari kelelahan transportasi. Rodalon sebagai desinfektan kandang dan peralatan baik tempat pakan maupun tempat minum. Vaksin ND 5 Ma Clone ${ }^{\circledR}, I_{B D}{ }^{\circledR}$ dan ND Lasota ${ }^{\circledR}$ untuk memberikan kekebalan terhadap tubuh broiler. Formalin $40 \%$ dan $\mathrm{KMnO}_{4}$ (kalium permanganat) untuk fumigasi kandang. Kapang Aspergillus niger sebagai bahan fermentasi kulit buah kakao. Vitamin seperti vitachick® sebagai suplemen tambahan.

\footnotetext{
Alat

Alat yang digunakan adalah kandang baterai berukuran $100 \mathrm{~cm} \times 100 \mathrm{~cm} \times 50 \mathrm{~cm}$, jumlah kandang sebanyak 24 unit dan tiap unit di isi 5 ekor Day old chick, peralatan kandang terdiri dari
} 
24 unit tempat minum dan 24 unit tempat pakan, timbangan salter dengan kapasitas $5 \mathrm{~kg}$ dengan kesetaraan $0,01 \mathrm{~g}$ untuk menimbang pertambahan bobot badan ayam, alat penerangan dan pemanas berupa lampu pijar 40 watt sebanyak 24 buah, Thermometer sebagai alat untuk mencatat suhu ruangan. alat pembersih kandang (sapu, sekop, hand sprayer dan lainnya), pisau, plastik, ember, alat tulis, buku data dan kalkulator. Terpal dengan ukuran 3 x 6 m sebanyak 4 buah sebagai penutup dinding ruangan.

\section{Metode Penelitian}

Adapun rancangan penelitian yang digunakan adalah rancangan acak lengkap (RAL) yang terdiri dari 6 perlakuan dan 4 ulangan dan setiap ulangan terdiri atas 5 ekor broiler.

Perlakuan yang diteliti adalah :

$\mathrm{R}_{0} \quad=$ Pakan komersial

$\mathrm{R}_{1}=$ Ransum formulasi dengan penggunaan dedak padi $12 \%$ dan tanpa kulit buah kakao fermentasi

$\mathrm{R}_{2}=$ Ransum formulasi dengan penggunaan dedak padi $9 \%$ dan kulit buah kakao fermentasi $3 \%$

$\mathrm{R}_{3}=$ Ransum formulasi dengan penggunaan dedak padi $6 \%$ dan kulit buah kakao fermentasi $6 \%$

$\mathrm{R}_{4}=$ Ransum formulasi dengan penggunaan dedak padi $3 \%$ dan kulit buah kakao fermentasi $9 \%$

$\mathrm{R}_{5} \quad=$ Ransum formulasi tanpa penggunaan dedak padi dan kulit buah kakao fermentasi $12 \%$

Tabel 1.Susunan dan kandungan nutrisi ransum periode starter

\begin{tabular}{lccccc}
\hline \multicolumn{1}{c}{ Komposisi pakan } & R1 & R2 & R3 & R4 & R5 \\
\hline T.Jagung & 47 & 47,1 & 47,1 & 47 & 47 \\
T.Ikan & 10 & 10 & 10 & 10 & 10 \\
B.kedelai & 25,3 & 25,2 & 25,2 & 25,2 & 25,2 \\
Dedak padi & 12 & 9 & 6 & 3 & 0 \\
P. Kakao F & 0 & 3 & 6 & 9 & 12 \\
Kapur & 1 & 1 & 1 & 1 & 1 \\
Top Mix & 0,7 & 0,7 & 0,7 & 0,8 & 0,8 \\
M. Nabati & 4 & 4 & 4 & 4 & 4 \\
\hline Total & 100 & 100 & 100 & 100 & 100 \\
\hline PK & 22,01 & 22,01 & 22,04 & 22.06 & 22.09 \\
EM & 3051,05 & 3052,52 & 3053,21 & 3050,53 & 3051,22 \\
SK & 3,57 & 3,91 & 4,26 & 4,6 & 4,94 \\
LK & 4,29 & 4,02 & 3,74 & 3,74 & 3,19 \\
Ca & 1,13 & 1,12 & 1,12 & 1.13 & 1,13 \\
P & 0,79 & 0,75 & 0,71 & 0,67 & 0,63 \\
\hline
\end{tabular}


Tabel 2. Susunan ransum finisher

\begin{tabular}{lccccc}
\hline Komposisi Pakan & R1 & R2 & R3 & R4 & R5 \\
\hline T.Jagung & 52,4 & 52,4 & 52,4 & 52,4 & 52,4 \\
T.Ikan & 8,0 & 8,0 & 8,0 & 8,0 & 8,0 \\
B.kedelai & 22,1 & 22,1 & 22,1 & 22,1 & 22,1 \\
Dedak padi & 12,0 & 9,0 & 6,0 & 3,0 & 0 \\
P. Kakao F & 0 & 3,0 & 6,0 & 9,0 & 12,0 \\
Kapur & 1,0 & 1,0 & 1,0 & 1,0 & 1,0 \\
Top Mix & 1,0 & 1,0 & 1,0 & 1,0 & 1,0 \\
M. Nabati & 3,5 & 3,5 & 3,5 & 3,5 & 3,5 \\
\hline Total & 100 & 100 & 100 & 100 & 100 \\
\hline PK & 20 & 20,03 & 20,06 & 20,09 & 20.12 \\
EM & 3054,48 & 3055,17 & 3055,85 & 3056,54 & 3057,22 \\
SK & 3,50 & 3,85 & 4,19 & 4,54 & 4,88 \\
LK & 4,34 & 4,06 & 3,79 & 3,51 & 3,24 \\
Ca & 1,04 & 1,04 & 1,03 & 1,03 & 1,03 \\
P & 0,71 & 0,67 & 0.63 & 0,59 & 0,55 \\
\hline
\end{tabular}

\section{Analisis data}

Model matematik percobaan yang digunakan adalah :

$$
\mathbf{Y i j}=\boldsymbol{\mu}+\boldsymbol{\sigma i}+\mathbf{\varepsilon i j}
$$

Keterangan :

$$
\begin{array}{ll}
\mathrm{i} & =1,2,3, \ldots \mathrm{i}=\text { perlakuan } \\
\mathrm{j} & =1,2,3, \ldots \mathrm{j}=\text { ulangan } \\
\mathrm{Yij} & =\text { nilai pengamatan pada perlakuan ke-i, ulangan ke-j } \\
\mu & =\text { nilai tengah umum } \\
\sigma \mathrm{i} & =\text { pengaruh perlakuan ke-i } \\
\text { \&ij } & =\text { efek } \mathrm{j} \text { galat pada perlakuan ke-i, ulangan ke- } \mathrm{j}
\end{array}
$$

\section{Parameter Peneletian}

\section{Konsumsi Ransum (g)}

Konsumsi ransum dihitung berdasarkan selisih antara jumlah ransum yang diberikan dikurangi dengan jumlah ransum yang sisa.

Konsumsi Ransum $=$ Ransum yang diberikan - ransum sisa 


\section{Pertambahan Bobot Badan (g)}

Pertambahan bobot badan diperoleh dengan menghitung selisih bobot badan akhir dengan selisih bobot badan awal. Penimbangan dilakukan setiap seminggu sekali.

Pertambahan Bobot Badan $=$ Bobot Badan Akhir - Bobot Badan Awal

\section{Konversi ransum}

Konversi ransum merupakan ratio antara konsumsi ransum dengan pertambahan bobot badan.

$$
\mathrm{FCR}=\frac{\text { banyaknya ransum yang dihabiskan }}{\text { berat badan yang diperoleh }}
$$

\section{HASIL DAN PEMBAHASAN}

\section{Rekapitulasi hasil penelitian}

Hasil penelitian tentang subsitusi dedak dengan pod kakao yang difermentasi dengan aspergillus niger terhadap performans broiler dapat dilihat pada Tabel 3.

Tabel 3. Rekapitulasi konsumsi ransum, pertambahan bobot badan dan konversi ransum ayam Broiler selama penelitian

\begin{tabular}{cccc}
\hline Perlakuan & $\begin{array}{c}\text { Konsumsi ransum } \\
\text { (gr/ekor/hari) }\end{array}$ & $\begin{array}{c}\text { Pertambahan bobot } \\
\text { badan (gr/ekor/hari) }\end{array}$ & Konversi ransum \\
\hline Ro & $96,08^{\mathrm{tn}} \pm 0,97$ & $54,99^{\mathrm{A}} \pm 1,74$ & $1,75^{\mathrm{A}} \pm 0,04$ \\
$\mathrm{R}_{1}$ & $94,93^{\mathrm{tn}} \pm 3,47$ & $45,63^{\mathrm{B}} \pm 0,66$ & $2,08^{\mathrm{B}} \pm 0,07$ \\
$\mathrm{R}_{2}$ & $94,66^{\mathrm{tn}} \pm 2,43$ & $45,47^{\mathrm{B}} \pm 0,77$ & $2,08^{\mathrm{B}} \pm 0,06$ \\
$\mathrm{R}_{3}$ & $94,24^{\mathrm{tn}} \pm 1,98$ & $45,13^{\mathrm{B}} \pm 0,87$ & $2,09^{\mathrm{B}} \pm 0,01$ \\
$\mathrm{R}_{4}$ & $94,00^{\mathrm{tn}} \pm 0,44$ & $41,41^{\mathrm{C}} \pm 0,38$ & $2,27^{\mathrm{C}} \pm 0,02$ \\
$\mathrm{R}_{5}$ & $92,64^{\mathrm{tn}} \pm 1,23$ & $40,06^{\mathrm{C}} \pm 2,43$ & $2,32^{\mathrm{C}} \pm 0,15$ \\
\hline
\end{tabular}

\section{Konsumsi Ransum}

Pengambilan data konsumsi ransum dilakukan setiap minggunya dengan cara pengurangan jumlah ransum yang diberikan dengan sisa ransum. Dari Tabel diatas dapat dilihat bahwa rataan konsumsi ransum broiler selama penelitian adalah 94,42gr/ekor/minggu. 
Konsumsi ransum terendah terdapat pada perlakuan R5 (ransum dengan perlakuan $0 \%$ dedak dan $12 \%$ pod kakao ) yaitu sebesar 92,64 gr/ekor/hari, sedangkan konsumsi ransum tertinggi terdapat pada perlakuan R0 (ransum dengan perlakuan pakan komersial ) sebesar 96,08 gr/ekor/hari. Pertumbuhan broiler yang cepat ada kalanya didukung oleh konsumsi ransum yang lebih banyak pula. Masalah konsumsi ransum memang harus disadari bahwa broiler ini senang makan. Bila ransum yang diberikan tidak terbatas atau ad libitum, ayam akan makan sepuasnya hingga kenyang (Rasyaf, 1997). Rataan konsumsi pakan ayam broiler selama enam minggu pengamatan mempunyai kisaran 2873,29-3124,67 g/ekor, dengan rataan yang dicapai sebesar 2993,59 g/ekor yaitu $106.91 \mathrm{~g} /$ ekor/hari.

Analisis ragam konsumsi pakan broiler diatas dapat dilihat bahwa pemberian ransum dedak, pod kakao, kombinasi maupun pakan komersial memberikan pengaruh yang tidak berbeda nyata $(\mathrm{P}<0,05)$. Hal ini dapat disebabkan karena tingkat protein dan energi metabolisme hampir sama dalam setiap level perlakuan. Hal ini sesuai dengan pernyataan Wahyu (1988), yang menyatakan tingkat protein dan energi metabolisme yang berbeda berpengaruh terhadap konsumsi pakan, selisih kandungan energi metabolisme pada setiap pakan perlakuan tidak jauh berbeda, sehingga ayam pada tiap perlakuan cenderung mengkonsumsi pakan yang sama. Kartadisastra (1994), menyatakan jumlah ransum yang diberikan sangat bergantung dari jenis ayam yang dipelihara, sistem pemeliharaan dan tujuan produksi. Disamping itu juga dipengaruhi oleh beberapa faktor yang berkaitan dengan genetik dan lingkungan tempat ternak itu dipelihara.

Hasil penelitian dapat dilihat bahwa konsumsi ransum broiler pada setiap perlakuan semakin menurun, pada peningkatan penggunaan pod kakao pada ransum menjadikan konsumsi ransumnya semakin menurun. Konsumsi pakan tertinggi terdapat pada R0 (pakan kontrol) dan konsumsi pakan terendah terdapat pada R5(ransum dengan perlakuan $0 \%$ dedak dan $12 \%$ pod kakao ). Hal ini dapat diakibatkan oleh semakin tingginya tingkat serat kasar pada ransum yang berasal dari pod kakao. Ini menunjukkan bahwa kandungan nutrisi ransum pada R0 sedikit lebih baik dari kandungan nutrisi pakan lainnya sehingga tingkat konsumsinya lebih baik.

\section{Pertambahan Bobot Badan}

Pengambilan data pertambahan bobot badan dilakukan setiap minggu dengan cara penimbangan bobot badan akhir dikurangi bobot badan sebelumnya dalam satuam 
gram/ekor/minggu. Dari hasil penelitian dapat dilihat bahwa rataan pertambahan bobot badan ayam broiler selama penelitian adalah 45,45 gr/ekor/minggu. Pertambahan bobot badan terendah terdapat pada perlakuan R5 (Ransum formulasi tanpa penggunaan dedak padi dan kulit buah kakao fermentasi 12\%) yaitu sebesar 40,06 gr/ekor/minggu, sedangkan pertambahan bobot badan tertinggi terdapat pada perlakuan R0 (pakan komersial) yaitu sebesar 54,99 gr/ekor/minggu. Hal ini sejalan dengan pendapat Murtidjo (2003), bahwa daging ayam broiler dipilih sebagai salah satu alternatif, karena seperti yang telah diketahui bahwa broiler sangat efisien diproduksi. Jangka waktu 6-8 minggu ayam tersebut sanggup mencapai berat hidup 1,5 $\mathrm{kg}-2 \mathrm{~kg}$ dan secara umum dapat memenuhi selera konsumen.

Hasil analisis ragam menunjukkan bahwa terdapat perbedaan yang sangat nyata pertambahan bobot badan antar perlakuan. Pada penggunaan pod kakao yang semakin tinggi mengakibatkan pertambahan bobot badan yang lebih rendah. Ini bisa diakibatkan oleh semakin tingginya tingkat serat kasar yang terdapat pada ransum. Siregar dan Sabrani (1970), menyatakan bahwa serat kasar yang berlebihan dapat mengurangi efisiensi penggunaan nutrien lain, sebaliknya apabila serat kasar ransum terlalu rendah, mengakibatkan ransum tidak dapat dicerna dengan baik.

Walaupun kandungan protein dan energi metabolisme pada setiap pakan sama, namun kandungan serat kasar yang tinggi pada pod kakao dapat mempengaruhi kecernaan pada ayam broiler. Hal ini sesuai dengan pernyataan Wahju (1992) yang menyatakan bahwa serat kasar yang tidak tercerna dapat membawa nutrien lain yang keluar bersama ekskreta. Hasil pertambahan bobot badan tertinggi terdapat pada perlakuan R0 (pakan komersial), sedangkan pertambahan bobot badan terendah terdapat pada R5 (Ransum formulasi tanpa penggunaan dedak padi dan kulit buah kakao fermentasi 12\%). Ini diakibatkan karena penggunaan pod kakao pada R5 lebih besar dari setiap perlakuaan dapat dilihat bahwa semakin banyak penggunaan pod kakao maka pertambahan bobot badannya semakin rendah.melalui uji duncan menunjukkan perbedaan pertambahan bobot badan antar perlakuan, dengan urutan dari yang terbesar adalah R0; R1; R2; R3; R4; R5.Jika dilihat dari uji duncan walaupun semakin turun tapi pertambahan bobot badan pada R1, R3 dan R3 tidak terlalu jauh tapi pada R4 dan R5 terjadi perbedaan yang nyata.Ini menunjukkan penggunaan pod kakao pada level $6 \%$ masih baik walaupun berbeda dengan R0 ( pakan komersial). 


\section{Konversi ransum}

Konversi ransum dapat dihitung dari perbandingan konsumsi ransum dengan pertambahan bobot badan yang dihasilkan selama penelitian. Konversi ransum adalah indikator teknis yang dapat menggambarkan tingkat efisiensi penggunaan ransum, semakin rendah angka konversi ransum berarti semakin efisien dan sebaliknya semakin tinggi angka konversi ransumnya maka semakin tidak efisien.

Tabel 1 dapat dilihat bahwa konversi ransum ayam broiler selama penelitian adalah 2,10. Konversi ransum terendah terdapat pada R0 (pakan komersial) yaitu sebesar 1,75. Sedangkan konversi ransum tertinggi terdapat pada R5 (ransum dengan $12 \%$ pod kakao dan $0 \%$ dedak padi) yaitu sebesar 2,32. Menurut hasil penelitian Muharlien,Achmanu dan Agung (2010) angka konversi ayam pedaging yang dipotong umur 6 minggu 1,76.

Hasil analisis ragam menunjukkan bahwa terdapat perbedaan yang sangat nyata konversi ransum antar perlakuan. Jika dilihat pada Tabel 3 bahwa konversi pakan terendah terdapat pada perlakuan R0 yaitu pakan komersial. Ini menunjukkan bahwa ransum pada R0 memiliki kualitas yang lebih baik. Sementara pada penggunaan pod kakao yang semakin tinggi mengakibatkan konversi pakan yang semakin tinggi pula, ini menunjukkan bahwa penggunaan pod kakao yang semakin tinggi mengakibatkan kualitas pakan yang semakin rendah. Rasyaf (2008) menjelaskan bahwa, konversi pakan adalah jumlah ransum yang dikonsumsi seekor ayam dalam waktu tertentu untuk membentuk daging atau berat badan. Faktor yang mempengaruhi tingkat konversi pakan antara lain strain, kualitas pakan, keadaan kandang dan jenis kelamin.

Tabel 1 melalui uji duncan dapat dilihat perbedaan konversi ransum antar perlakuaan dengan urutan dari yang terkecil adalah R0; R1; R2; R3; R4; R5. Dalam penelitian ini ransum terbaik adalah ransum R0 (pakan komersial), sedangkan pakan terburuk adalah R5 (ransum dengan $12 \%$ pod kakao dan $0 \%$ dedak padi).

Menurut Rasyaf (1992), konversi ransum adalah ransum yang habis dikonsumsi ayam dalam jangka waktu tertentu dibandingkan dengan pertumbuhan bobot badan (pada waktu tertentu) semakin baik mutu ransum semakin kecil konversinya. Dalam penelitian ini ransum terbaik adalah ransum R0 (pakan komersial), sedangkan pakan terburuk adalah R5 (ransum dengan $12 \%$ pod kakao dan $0 \%$ dedak padi).

\section{KESIMPULAN}


Subsitusi dedak padi dengan pod kakao yang difermentasi dengan Aspergillus niger masih memberikan pengaruh positif sampai level penggunaan $6 \%$ dan tidak mengurangi nilai nutrisi ransum pada ayam broiler umur 6 minggu(42 hari).

\section{DAFTAR PUSTAKA}

Amirroenas D. E. 1990. Mutu ransum berbentuk pellet dengan bahan serat biomasa pod kakao (Theobroma cacao L.) untuk pertumbuhan sapi perah jantan. Tesis Sekolah Pascasarjana, Institut Pertanian Bogor, Bogor.

Anggorodi,H.R.,1995. Nutrisi Aneka Ternak Unggas.Gramedia Pustaka Utama, Jakarta.

Kartadisastra, H.R.,1994. Pengelolaan Pakan Ayam. Konsius. Yogyakarta.

Muharlien,Achmanu,Agung K.2010.Effek Lama Waktu Pembatasan Pemberian PakanTerhadap Performan Ayam Pedaging. Jurnal TernakTropika Vol. Jurusan Proter.Fapet. UB Malang.

Murtidjo, B.A., 2003. Pedoman Beternak Ayam Broiler. Kanisius, Yogyakarta.

Laboratorium Ilmu Nutrisi dan Pakan Ternak, 2010. Hasil Analisis Kulit Kakao Fermentasi. Program Studi Perternakan FP USU, Medan.

Rasyaf, M. 1997. Pengelolaan Peternakan Unggas Pedaging. Kanisius.Yogyakarta

Rasyaf, M. 2008. Panduan Beternak Ayam Pedaging. Penebar Swadaya. Jakarta.

Siregar, A.P., dan M. Sabrani. 1970. Teknik Modern Beternak Ayam. Yasaguna. Jakarta.

Siregar, Z.,1974. Pemenfaatan Hasil Samping Perkebunan dengan Penambahan Mineral dan Hidrolisat Bulu Ayam. Universitas Sumatera Utara, Medan.

Wahyu, J., 1992, Ilmu Nutrisi Unggas, Universitas Gajah Mada Press, Yogyakarta. 